\title{
The effects of feeding rations that differ in neutral detergent fiber and starch concentration within a day on production, feeding behavior, total-tract digestibility, and plasma metabolites and hormones in dairy cows
}

\author{
L. W. Rottman, ${ }^{1}$ Y. Ying, K. Zhou, P. A. Bartell, and K. J. Harvatine ${ }^{2}$ \\ Department of Animal Science, Penn State University, University Park 16802
}

\begin{abstract}
Dairy cows exhibit a daily pattern of feed intake and milk synthesis, and feeding a single total mixed ration over the day may not synchronize ruminal fermentation, nutrient absorption, and milk synthesis. Our hypothesis was that feeding a high-fiber diet during the high-intake period of the day and a low-fiber diet during the low-intake overnight period would stabilize rumen fermentation, nutrient absorption, and the availability of nutrients for milk synthesis. Nine ruminally cannulated cows were used in a $3 \times 3$ Latin square design with 23 -d periods. Diets were a control [CON; $33.3 \%$ neutral detergent fiber (NDF)], a low-fiber diet (LF; $29.6 \% \mathrm{NDF}$ ), and a high-fiber diet (HF; 34.8\% NDF). The HF and LF diets were balanced to provide the same nutrient composition as the control diet when cows were fed a 7:3 ratio of HF:LF. Control cows were fed once daily at $0900 \mathrm{~h}$. Cows in the high/low treatment $(\mathrm{H} / \mathrm{L})$ were fed $\mathrm{HF}$ at $70 \%$ of daily offering at $0900 \mathrm{~h}$ and $\mathrm{LF}$ at $30 \%$ of daily offering at $2200 \mathrm{~h}$; cows in the low/high $(\mathrm{L} / \mathrm{H})$ treatment were fed $\mathrm{LF}$ at $30 \%$ of daily offering at $0900 \mathrm{~h}$ and $\mathrm{HF}$ at $70 \%$ of daily offering at $1300 \mathrm{~h}$. Dry matter intake was decreased $1.9 \mathrm{~kg} / \mathrm{d}$ by $\mathrm{H} / \mathrm{L}$ compared with $\mathrm{CON}$, but intake did not differ between $\mathrm{H} / \mathrm{L}$ and $\mathrm{L} / \mathrm{H}$. The $\mathrm{H} / \mathrm{L}$ and $\mathrm{L} / \mathrm{H}$ treatments resulted in a large amount of feed consumed after each feeding, which shifted the daily patterns of starch and fiber intake. Treatments did not differ in total-tract digestibility. We detected no differences between CON and $\mathrm{H} / \mathrm{L}$ for milk yield and composition. The $\mathrm{H} / \mathrm{L}$ treatment unexpectedly tended to reduce milk and reduced milk fat yield compared with $\mathrm{L} / \mathrm{H}$, although $\mathrm{L} / \mathrm{H}$ was expected to result in poorer rumen fermentation and decreased milk fat yield. Treatment did not affect milk fat concentrations of trans-10 C18:1, trans-11 C18:1,
\end{abstract}

\footnotetext{
Received September 15, 2014.

Accepted December 30, 2014.

${ }^{1}$ Currrent address: Novozymes Biologicals Inc., Salem, VA 24153.

${ }^{2}$ Corresponding author: kjh182@psu.edu
}

or de novo synthesized fatty acids, but $\mathrm{H} / \mathrm{L}$ increased milk fat concentration of preformed fatty acids compared with CON (39.15 vs. $37.38 \%$ of FA, respectively). Treatment had no effect on plasma insulin or glucose at individual time points but did modify the phase and amplitude of the daily rhythms. Daily average plasma nonesterified fatty acids (NEFA) were decreased by $\mathrm{H} / \mathrm{L}$ compared with $\mathrm{CON}$ and $\mathrm{L} / \mathrm{H}$, and $\mathrm{H} / \mathrm{L}$ treatments decreased the amplitude of the daily rhythm of NEFA by 3.4 and $6.7 \mu \mathrm{Eq} / \mathrm{L}$ compared with $\mathrm{CON}$ and $\mathrm{L} / \mathrm{H}$, respectively. The amplitude of the daily rhythm of plasma blood urea $\mathrm{N}$ was increased by more than $15 \%$ by $\mathrm{H} / \mathrm{L}$ compared with $\mathrm{CON}$ and $\mathrm{L} / \mathrm{H}$. Feeding multiple rations over the day changed the daily pattern of starch and fiber intake and decreased daily intake without decreasing milk yield or body weight gain over the 23-d observation periods. Feeding a high-fiber diet during the high-intake period of the day and a lowfiber diet during the low-intake overnight period failed to show other benefits, likely because of the change in feeding behavior.

Key words: circadian, diurnal, feed intake

\section{INTRODUCTION}

Cattle have naturally occurring daily patterns of feeding, with higher rates of intake occurring around dawn and dusk in pasture-fed animals (Albright, 1993). Total mixed rations, which are typically fed 1 to 3 times per day, are used to supply a constant composition of nutrients in each meal and minimize the detrimental effects of high-starch diets (Coppock et al., 1981). Environmental factors influencing feeding behavior have been extensively investigated and these include the frequency and timing of feed delivery, stocking density, and cow parity (reviewed by von Keyserlingk and Weary, 2010). For example, increasing the number of times per day that a TMR is fed can change the daily pattern of feed intake by shifting intake toward the times feed is delivered (DeVries et al., 2003, 2005). In addition to the distinct daily pattern of intake, cows have the ability to sort TMR and tend to consume a more fermentable 
diet during the first part of the day (DeVries et al., 2005). The daily pattern of intake and sorting causes fluctuations in the rate of nutrients entering the rumen and is expected to change rumen digesta composition, but TMR feeding generally does not consider the daily pattern of intake.

Diet nutrient concentration and diet composition affect rumen digestion rates (Firkins et al., 1998), and changes in the rate of nutrient entry into the rumen over the day are also expected to affect rumen digestion rates. Additionally, feed intake increases passage rates and may modify rumen dynamics (Girard, 1990). These observations directly contradict the steady state rumen environment assumed during TMR feeding by many nutritionists and models of digestion kinetics (Mertens, 1987). Taken together, the natural daily pattern of feed intake, feed delivery time, and sorting creates a daily rhythm of nutrient entry into the rumen that is not constant throughout the day and should be taken into account when designing feeding strategies.

It is commonly recognized that milk yield and composition vary over the day. Generally, higher milk yields are observed at the morning milking than at the evening milking, whereas fat percentage is higher at the evening milking than at the morning milking (Everett and Wadell, 1970; Quist et al., 2008). We recently reported a daily pattern of milk and milk component synthesis observed when milking $4 \times / \mathrm{d}$ that was modified by feeding 4 equal meals every $6 \mathrm{~h}$ over the day compared with feeding once per day (Rottman et al., 2014). The daily rhythm of milk synthesis that is partly dependent on the timing of feed intake indicates that nutrient absorption may not always be synchronized with the timing of nutrients required for maximal milk synthesis.

Feed sorting, feeding a single TMR over the day, and the natural daily pattern of feed intake create large variations in the amount of fermentable carbohydrate entering the rumen over the day. This is not ideal for stable rumen fermentation and maximal milk synthesis over the entire day. Our hypothesis was that feeding a higher fiber ration during the high-intake period of the day and a lower fiber ration during the low-intake period during the night would stabilize rumen fermentation, nutrient absorption, and the availability of nutrients for milk synthesis. This strategy was compared with the current industry standard of feeding a single TMR once per day and the inverse feeding strategy that fed a low-fiber diet during the high-intake period after morning feeding and a high-fiber diet during the low-intake period during the night that was expected to increase the amount of starch consumed after the morn- ing feeding. This paper reports the effects on intake and feeding behavior, total-tract digestibility, milk production, milk FA profile, and selected plasma metabolites and hormones. A companion paper (Ying et al., 2015) focuses on the effect in the rumen and reports the effect of treatment on rumen digesta nutrient concentration and pool size and rumen $\mathrm{pH}$ over the day.

\section{MATERIALS AND METHODS}

\section{Animals and Experimental Design}

Nine multiparous Holstein cows $(158 \pm 48$ DIM, mean $\pm \mathrm{SD}$ ) from the Pennsylvania State University Dairy Herd were randomly assigned to 1 of 3 treatments in a $3 \times 3$ Latin square design with 23 -d periods. Cows were housed in tie stalls, and lights were manually controlled with a dark phase from approximately 0000 to $0500 \mathrm{~h}$. All animal procedures were approved by the Pennsylvania State University Institutional Animal Care and Use Committee (\#31694). The 3 diets used included a control (CON; $33.1 \%$ NDF), a low-fiber diet (LF; $29.6 \%$ NDF), and a high-fiber diet (HF; 34.8\% NDF; Table 1). Forage was substituted for corn grain to change diet NDF, and the HF and LF diets were balanced to offer the same diet nutrient composition as the CON diet when cows were fed a 7:3 ratio of HF:LF. Cows on CON were fed the control TMR at $0900 \mathrm{~h}$; cows on the high/low treatment $(\mathbf{H} / \mathbf{L})$ were fed HF at $70 \%$ of daily offering at $0900 \mathrm{~h}$ and $\mathrm{LF}$ at $30 \%$ of daily offering at $2200 \mathrm{~h}$; and cows on the low/high $(\mathbf{L} / \mathbf{H})$ treatment were fed LF at 30\% of daily offering at 0900 $\mathrm{h}$ and $\mathrm{HF}$ at $70 \%$ of daily offering at $1300 \mathrm{~h}$ (Figure 1). All cows were fed at $110 \%$ of expected daily intake. Refused feed was removed before delivery of new feed at each feeding.

\section{Milk Sampling and Analysis}

Cows were milked twice a day at 0700 and $1700 \mathrm{~h}$ in a parlor and milk yield measured using an integrated milk meter (AfiMilk; SAE Afikim, Kibbutz Afikim, Israel). Milk was sampled at each milking from d 18 to 20 of each period. One subsample was stored at $4^{\circ} \mathrm{C}$ with a liquid preservative (Bronolab-WII; Advanced Instruments Inc., Norwood, MA) until analyzed for fat (filter B), protein, and MUN by infrared spectroscopy (4000 Milko-Scan, Foss Electric, Hillerød, Denmark; AOAC International, 2000, method 972.160; Dairy One Laboratory, State College, PA). Milk FA profile was determined at each milking on d 20, as described by Rico and Harvatine (2013). 
Table 1. Ingredient and nutrient composition (\% of DM unless otherwise noted) of experimental diets

\begin{tabular}{|c|c|c|c|}
\hline \multirow[b]{2}{*}{ Item } & \multicolumn{3}{|c|}{$\operatorname{Diet}^{1}$} \\
\hline & $\mathrm{CON}$ & $\mathrm{HF}$ & $\mathrm{LF}$ \\
\hline \multicolumn{4}{|l|}{ Dietary ingredient } \\
\hline Corn silage $^{2}$ & 38.8 & 41.7 & 32.1 \\
\hline Ground corn & 19.3 & 15.1 & 29.1 \\
\hline Alfalfa haylage ${ }^{3}$ & 12.6 & 13.5 & 10.4 \\
\hline Canola meal & 9.6 & 9.6 & 9.6 \\
\hline Cracked roasted soybeans & 7.2 & 7.2 & 7.2 \\
\hline Grass hay and straw ${ }^{4}$ & 4.1 & 4.5 & 3.4 \\
\hline Cookie meal & 3.3 & 3.3 & 3.3 \\
\hline Vitamin-mineral mix $^{5}$ & 3.2 & 3.2 & 3.2 \\
\hline Cottonseed hulls & 1.41 & 1.51 & 1.16 \\
\hline $\mathrm{NPN}^{6}$ & 0.42 & 0.42 & 0.42 \\
\hline \multicolumn{4}{|l|}{ Nutrient composition } \\
\hline $\mathrm{OM}$ & 93.8 & 93.3 & 93.7 \\
\hline $\mathrm{NDF}$ & 33.3 & 34.8 & 29.6 \\
\hline Starch & 28.6 & 27.2 & 31.9 \\
\hline $\mathrm{CP}$ & 15.9 & 16.0 & 15.7 \\
\hline Fatty acids & 3.9 & 3.8 & 4.1 \\
\hline Mean particle size, ${ }^{7} \mathrm{~mm}$ & 7.2 & 7.3 & 5.9 \\
\hline
\end{tabular}

${ }^{1} \mathrm{CON}=$ control; $\mathrm{HF}=$ high-fiber diet; $\mathrm{LF}=$ low-fiber diet.

${ }^{2}$ Contained $39.6 \%$ NDF, $37.0 \%$ starch, and $7.0 \%$ CP on a DM basis.

${ }^{3}$ Contained $51.1 \%$ NDF and $21.0 \% \mathrm{CP}$ on a DM basis.

${ }^{4}$ Mixed grass hay and wheat straw mixture. Contained $74.7 \%$ NDF and $6.4 \% \mathrm{CP}$ on a DM basis.

${ }^{5}$ Vitamin and mineral mix contained: $11 \% \mathrm{CP}, 18 \% \mathrm{NDF}, 5.1 \%$ fat, $14 \% \mathrm{Ca}, 0.35 \% \mathrm{P}, 4.6 \% \mathrm{Mg}, 0.42 \% \mathrm{~K}, 0.3 \% \mathrm{~S}, 1,071 \mathrm{mg} / \mathrm{kg} \mathrm{Mn}, 357$ $\mathrm{mg} / \mathrm{kg} \mathrm{Cu}, 1,085 \mathrm{mg} / \mathrm{kg} \mathrm{Zn}, 6.66 \mathrm{mg} / \mathrm{kg}$ Se, $6.4 \%$ salt (DM basis), $262,101 \mathrm{IU} / \mathrm{kg}$ of vitamin A, 65,421 IU/ $\mathrm{kg}$ of vitamin D, and 1,972 IU/ $\mathrm{kg}$ of vitamin $\mathrm{E}$ (DM basis).

${ }^{6}$ Optigen (Alltech Inc., Nicholasville, KY; 256\% CP, DM basis).

${ }^{7}$ Measured with the Penn State Particle Separator (Lammers et al., 1996). Percentages on the 19-, 8-, 4-mm sieves, and bottom pan were $12.2,36.9,27.0$, and 23.9 for CON; 15.4, 33.7, 26.0, and 25.0 for HF; and $10.0,28.9,25.6$, and $35.5 \%$ for LF.

\section{Feeding Behavior Observation}

Cows were housed in an automated feed intake observation system similar to that described in Dado and Allen (1993). Briefly, hanging feed tubes were suspended from an electronic load cell wired to a data acquisition system (RLWS 920i; Rice Lake Weighing System, Rice Lake, WI). Feed weight was recorded every $10 \mathrm{~s}$ from d 14 to 20 of each period. An algorithm developed in IGOR (WaveMetrics Inc., Lake Oswego, OR; algorithm provided by M. S. Allen, Michigan State University, East Lansing) determined the number and size of meals using $8 \mathrm{~min}$ as the minimum intermeal interval and $0.45 \mathrm{~kg}$ of $\mathrm{DM}$ as the minimum meal size, according to Harvatine and Allen (2006a). Satiety ratio was calculated as meal size divided by the post-meal interval, and hunger ratio was calculated as meal size divided by the preceding intermeal interval. Intake rate (\% of daily intake per hour) was calculated over 30-min intervals for $24 \mathrm{~h}$. Raw data were smoothed by averaging over

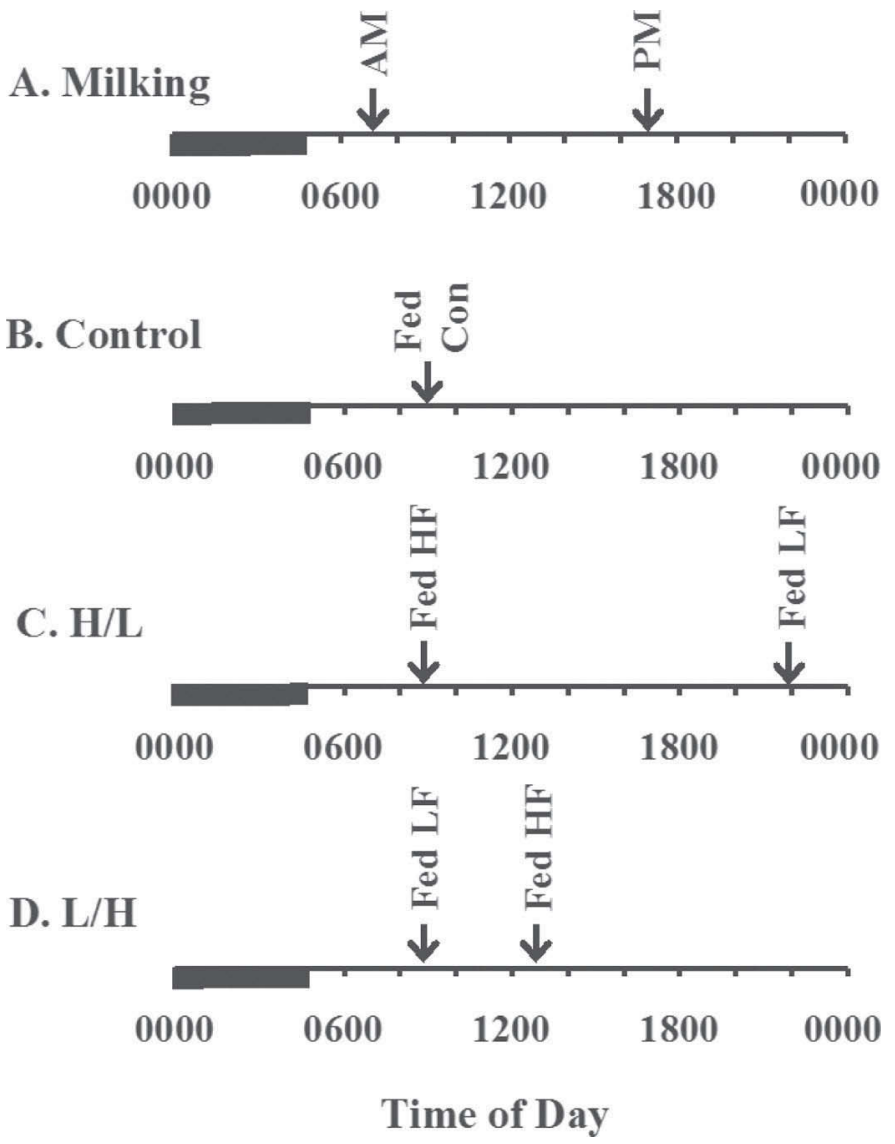

Figure 1. Timing of feeding and milking of 3 treatments tested. All cows were milked at 0700 and $1700 \mathrm{~h}$ each day. Control (Con) diet was fed as a TMR once per day at $0900 \mathrm{~h} ; \mathrm{H} / \mathrm{L}$ was fed as high-fiber (HF) ration at $70 \%$ of daily offering at $0900 \mathrm{~h}$ and low-fiber $(\mathrm{LF})$ ration at $30 \%$ of daily offering at $2200 \mathrm{~h}$; and $\mathrm{L} / \mathrm{H}$ was fed as low-fiber ration at $30 \%$ of daily offering at $0900 \mathrm{~h}$ and high-fiber diet at $70 \%$ of daily offering at $1300 \mathrm{~h}$. Dark phase is shown by the black bar.

$180 \mathrm{~s}$, and the rate of feed intake was calculated every $10 \mathrm{~s}$ over 10 -min intervals and averaged over $2 \mathrm{~h}$.

\section{Feed and Fecal Sampling and Analysis}

Orts were weighed and subsampled (12.5\%) from d 15 to 17 and composited by period. Individual feeds and TMR were collected using the quartering method. Fecal grab samples were collected 8 times from d 15 to 17 to represent every $3 \mathrm{~h}$ of the day and composited by period. All samples were dried at $55^{\circ} \mathrm{C}$ in a forced air oven. Individual forages and a representative mixture of concentrate feeds were analyzed for DM, CP, starch, $\mathrm{NDF}$, indigestible (i)NDF, ADF, and FA concentration according to Rico et al. (2014). Orts and feces were also analyzed for starch, NDF, and iNDF, and apparent total-tract digestibility was determined based on iNDF as an internal marker. 


\section{Blood Sampling and Analysis}

Indwelling jugular catheters were placed on d 14, and blood samples were collected in potassium EDTA tubes (Greiner Bio-One North America Inc., Monroe, NC) every $9 \mathrm{~h}$ on d 15 to 17 to represent every $3 \mathrm{~h}$ of the day. Blood was immediately placed on ice, centrifuged within $1 \mathrm{~h}$ at $2,200 \times g$ for $15 \mathrm{~min}$ at $4^{\circ} \mathrm{C}$, and plasma was stored at $-20^{\circ} \mathrm{C}$ until further analysis. Plasma samples were analyzed for insulin, glucose, BUN, and NEFA using commercial kits, as described by Rottman et al. (2014).

\section{BW and Energetic Calculations}

Rumen digesta was completely evacuated and rumen empty BW (EBW) was recorded at approximately $0800 \mathrm{~h}$ immediately before the first period and on the last day of each period. Feed efficiency was calculated as $\left(\mathrm{NE}_{\mathrm{L}}\right.$ milk $+\mathrm{NE}_{\mathrm{L}}$ EBW change)/DMI, with $\mathrm{NE}_{\mathrm{L}}$ calculated according to Table 2-4 of NRC (2001) using BCS determined according to Wildman et al. (1982).

\section{Statistical Analysis}

Daily parameters including intake, digestibility, milk yield and composition, BW change, and feeding behavior parameters were analyzed by the Fit model function of JMP Pro (v9.0 and 10.0; SAS Institute Inc., Cary, NC). The model included the random effect of cow, period, and treatment sequence (6 treatment sequences, with 3 used twice and 3 used once; treatments were equally represented in each period and selected to balance 6 of the assigned sequences, but 3 were unbalanced) and the fixed effect of treatment. A reduced model was used based on the model-adjusted $\mathrm{R}^{2}$. Preplanned contrasts were $\mathrm{CON}$ versus $\mathrm{H} / \mathrm{L}$ and $\mathrm{H} / \mathrm{L}$ versus $\mathrm{L} / \mathrm{H}$. Feed intake and feeding behavior by diet for $\mathrm{H} / \mathrm{L}$ and $\mathrm{L} / \mathrm{H}$ treatments were analyzed with a similar model that included the effect of treatment, diet, and interaction of treatment and diet. Time-course response variables including milk production by milking and plasma metabolite and hormones were analyzed using the MIXED procedure of SAS with repeated measures (SAS Institute Inc.). Fixed effects were treatment, time, and the interaction of treatment and time. Random effects were cow(sequence), sequence, and period; subject was cow $\times$ period. A reduced model was used based on the Bayesian information criterion score. Preplanned contrasts were tested at each time point, and the Kenward Rogers denominator degrees of freedom adjustment was used. Significance and tendencies were declared at $P<$ 0.05 and $P<0.10$, respectively.
Circadian rhythm analysis of plasma metabolites and hormones was conducted by fitting the linear form of a cosine function with a 24 -h period by random regression, as described by Rottman et al. (2014). A zero amplitude test was used to determine if each treatment fit the cosine function, and phase (time of peak) and amplitude (peak - mean) were calculated for each rhythm.

\section{RESULTS AND DISCUSSION}

The study was designed to test feeding strategies that fed multiple rations differing in fermentability over the day. To provide an appropriate control that delivered comparable nutrients per day, it was essential to feed the LF and HF diets at a set ratio (7:3) so that their combination resulted in the same daily ration as CON. This limited how different the LF and HF diets could be in their starch and fiber concentrations and how much of each could be fed. The selected ratio provided diets that differed in NDF by 5.3 percentage units (Table 1). Additionally, based on previous experiments, cows fed a TMR $1 \times / \mathrm{d}$ in the morning normally consumed approximately $30 \%$ of their daily intake in the first $3 \mathrm{~h}$ after feeding. Diet NDF and starch were changed by a simple substitution of a constant proportion of high-fiber feeds (forages and cottonseed hulls) for ground corn while keeping other ingredients constant (Table 1). Substitution of feed ingredients affects many nutrients and nutrient fractions, but the major nutrient differences were NDF and starch; CP was similar between diets (within 0.3 percentage units). This approach was taken to reduce confounding factors arising from changing multiple ingredients to balance other parameters, for example, protein and protein fractions, between diets.

Substitution of ground corn for forage reduced particle size (Table 1) and was expected to reduce effective fiber and increase the rate and extent of fermentation of the LF diet. Reducing forage may also increase passage rate and modify microbial protein synthesis. Other possible methods to change diet fermentability would be to change processing methods. For example, substituting steam-flaked corn for cracked corn would create different rates of fermentation without changing nutrient composition (San Emeterio et al., 2000).

\section{Daily Feed and Nutrient Intakes}

The goal of the experiment was to provide a lowstarch diet during the high-intake period observed after morning feeding and a high-starch diet during the lowintake period during the night. The treatments were 
designed to test an applied feeding strategy and were confounded by feeding frequency and feeding time between treatments. Feeding times were determined by preliminary analysis of feeding behavior observed in a feed observation system and manual observation during previous experiments. The timing of the first feeding was determined by the milking and farm feeding schedule, and the timing of the second feeding was determined based on the predicted time required to consume the amount of feed delivered, with adjustments based on the rate of intake in the first days of the experiment.

Total daily DMI decreased $1.9 \mathrm{~kg} / \mathrm{d}$ and intakes of NDF and starch decreased 0.6 and $0.5 \mathrm{~kg} / \mathrm{d}$, respectively, by $\mathrm{H} / \mathrm{L}$ compared with CON (Table 2). However, daily intake did not differ between $\mathrm{H} / \mathrm{L}$ and $\mathrm{L} / \mathrm{H}$. Daily intake is regulated centrally by the integration of many factors, including signals sensing energy balance in multiple tissues and physical fill of the gut. Feeding the HF diet during the active feeding period of the day in the $\mathrm{H} / \mathrm{L}$ treatment may have created a physical fill limitation during the preferred feeding period.

The $\mathrm{H} / \mathrm{L}$ and $\mathrm{L} / \mathrm{H}$ diets were designed to deliver the same daily nutrients, but feed sorting and differences in the amounts of feed refusals with each diet provided an opportunity for cows to consume nutrients in proportions different from that designed. The $\mathrm{H} / \mathrm{L}$ treatment resulted in $0.6 \mathrm{~kg} / \mathrm{d}$ higher intake of the $\mathrm{LF}$ diet and $1.4 \mathrm{~kg}$ lower intake of the HF diet compared with the $\mathrm{L} / \mathrm{H}$ treatment (Table 2), which subsequently resulted in changes in the NDF and starch delivered with each diet. Although cows differed slightly in the proportion of each diet consumed $(\mathrm{H} / \mathrm{L}$ consumed $31.8 \% \mathrm{~L}$ and $68.2 \% \mathrm{H}$ and $\mathrm{L} / \mathrm{H}$ consumed $28.4 \% \mathrm{~L}$ and $71.6 \% \mathrm{H}$ ), the average NDF and starch concentrations of feed consumed over the day did not differ between treatments (average NDF was 33.0, 33.1, and 33.0\% for control, $\mathrm{H} / \mathrm{L}$, and $\mathrm{L} / \mathrm{H}$; average starch concentration was $28.8 \%$ for all treatments; Table 2). The ability to select is dependent on the targeted level of refusals. A stricter design could have reduced the refusal rate but would have resulted in no refusals and may have limited daily intake.

\section{Daily Pattern of Feeding Behavior}

Cows have a naturally occurring daily pattern of feed intake (DeVries et al., 2003) with higher and lower levels of intake across the day (Tolkamp et al., 2011). In cows fed a TMR once per day in the morning, the highest rate of intake occurs after the morning feeding and during the late afternoon (e.g., Niu et al., 2014). In the current experiment, we detected a treatment by time of day interaction for the daily pattern of DM, starch, and NDF intakes reported as a percentage of total daily intake $(P<0.001 ;$ Figure 2$)$. The $\mathrm{L} / \mathrm{H}$ and $\mathrm{H} / \mathrm{L}$ treatments increased the proportion of $\mathrm{DM}$ and starch consumed after feeding the LF diet, and the H/L treatment also increased NDF intake after feeding the

Table 2. The effect of feeding a single TMR or 2 rations that differ in their fiber and starch concentrations at different times of the day on intake and composition of diets consumed

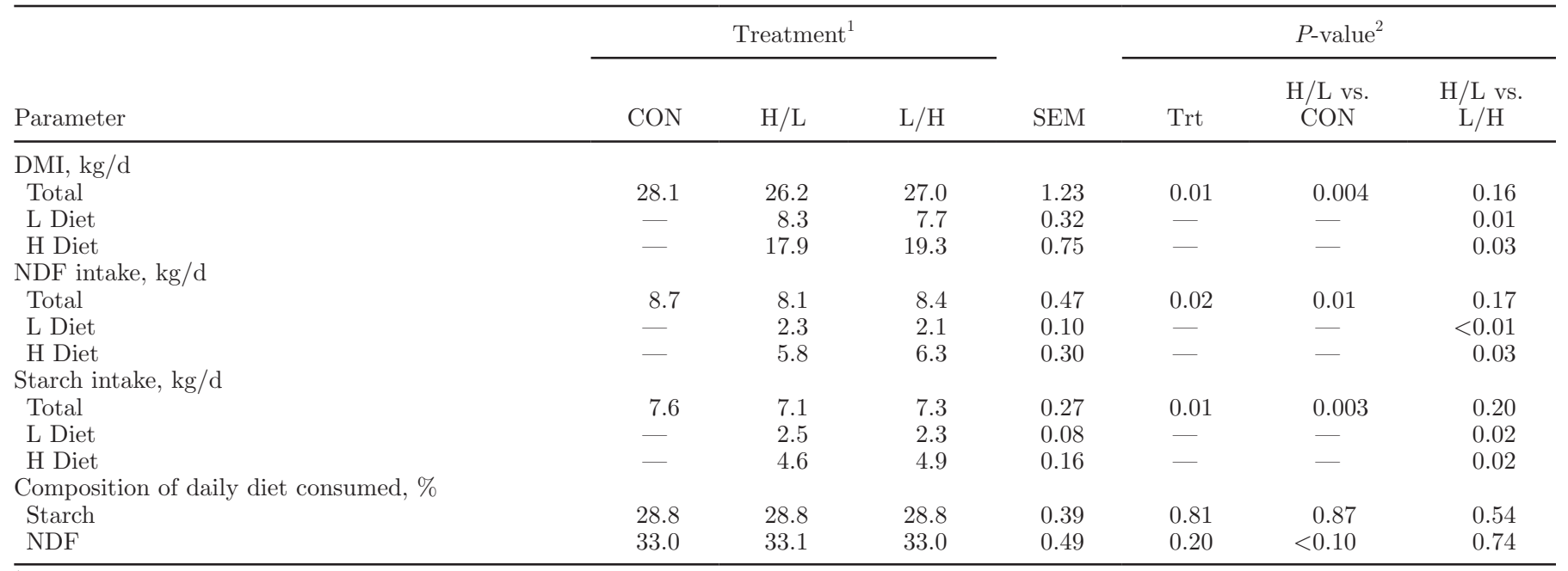

${ }^{1}$ Least squares means. The control (CON) cows were fed a TMR once per day at $0900 \mathrm{~h} ; \mathrm{H} / \mathrm{L}$ were fed a high-fiber ration at $70 \%$ of daily offering at $0900 \mathrm{~h}$ and a low-fiber ration at $30 \%$ of daily offering at $2200 \mathrm{~h}$; and $\mathrm{L} / \mathrm{H}$ were fed a low-fiber ration at $30 \%$ of daily offering at $0900 \mathrm{~h}$ and a high-fiber diet at $70 \%$ of daily offering at $1300 \mathrm{~h}$.

${ }^{2}$ Main effect of treatment (Trt) and preplanned contrasts (H/L vs. CON and H/L vs. L/H).

${ }^{3} \mathrm{EBW} \Delta=$ average rumen empty BW (EBW) change per day during each period.

${ }^{4}$ Efficiency (Mcal of $\mathrm{NE}_{\mathrm{L}}$ per $\mathrm{kg}$ of DMI) calculated as $\left(\mathrm{NE}_{\mathrm{L}}\right.$ milk $+\mathrm{NE}_{\mathrm{L}} \mathrm{EBW}$ change)/DMI based on NRC (2001). 
LF diet because of the low level of intake in other treatments at that time (Figure 2). In the $\mathrm{H} / \mathrm{L}$ treatment, DMI was lower before the LF feeding (1730 to $2130 \mathrm{~h}$ ) and starch intake was lower during the early morning (0330 to $0730 \mathrm{~h}$ ) compared with that in CON. The goal of $\mathrm{H} / \mathrm{L}$ was to increase the amount of starch entering the rumen during the overnight period. However, offering fresh feed is a strong stimulus for feeding, and feeding the LF diet in the evening resulted in a greater proportion of intake being consumed immediately after feeding. Similarly, feeding a TMR in the evening has been reported to result in a larger proportion of feed being consumed immediately after feeding compared with feeding a TMR in the morning (Nikkhah et al., 2008; Niu et al., 2014). This highlights a difficulty in feeding multiple rations over the day, as the timing of feeding modifies the pattern of intake. An alternate approach to control for the influence of offering fresh feed would have been feeding all treatments at both times (e.g., control receiving additional control diet in the evening). However, the goal of the experiment was to test the proposed novel feeding strategies compared with the conventional once-per-day TMR feeding. Last, cows were housed in the same barn, and cows in different treatments were interspersed between each other in the barn. Offering feed to cows on other treatments may have modified feeding behavior, but it appears that this had little effect because no increase in intake was observed in treatments that were not offered fresh feed (Figure 2), similar to the minimal effect observed in other experiments feeding TMR at different times in the same facility (Niu et al., 2014). It appears that the stimulus for consumption is fresh feed availability, not activity within the barn.

\section{Meal Parameters}

Daily intake is the product of the number of meals consumed per day and average meal size. Treatments had no effect on the number or size of meals over the day, but $\mathrm{H} / \mathrm{L}$ did decrease daily time spent eating by $32 \mathrm{~min} / \mathrm{d}$ compared with CON and tended to decrease eating rate within meals (Table 3). Additionally, H/L decreased the hunger ratio by $25 \%$ compared with CON $(P<0.01)$, indicating that the change in intake was due to a decrease in hunger rather than satiety.

To investigate an interaction of diet and time of feeding, we analyzed feeding behavior while cows consumed the $\mathrm{LF}$ and $\mathrm{HF}$ diets in the $\mathrm{H} / \mathrm{L}$ and $\mathrm{L} / \mathrm{H}$ treatments. We detected an interaction of diet and treatment for meal size, meal number, meal interval, time spent eating, eating rate, and hunger and satiety ratios (Table 4). Meal size was $0.7 \mathrm{~kg}$ larger for $\mathrm{LF}$ when it was fed
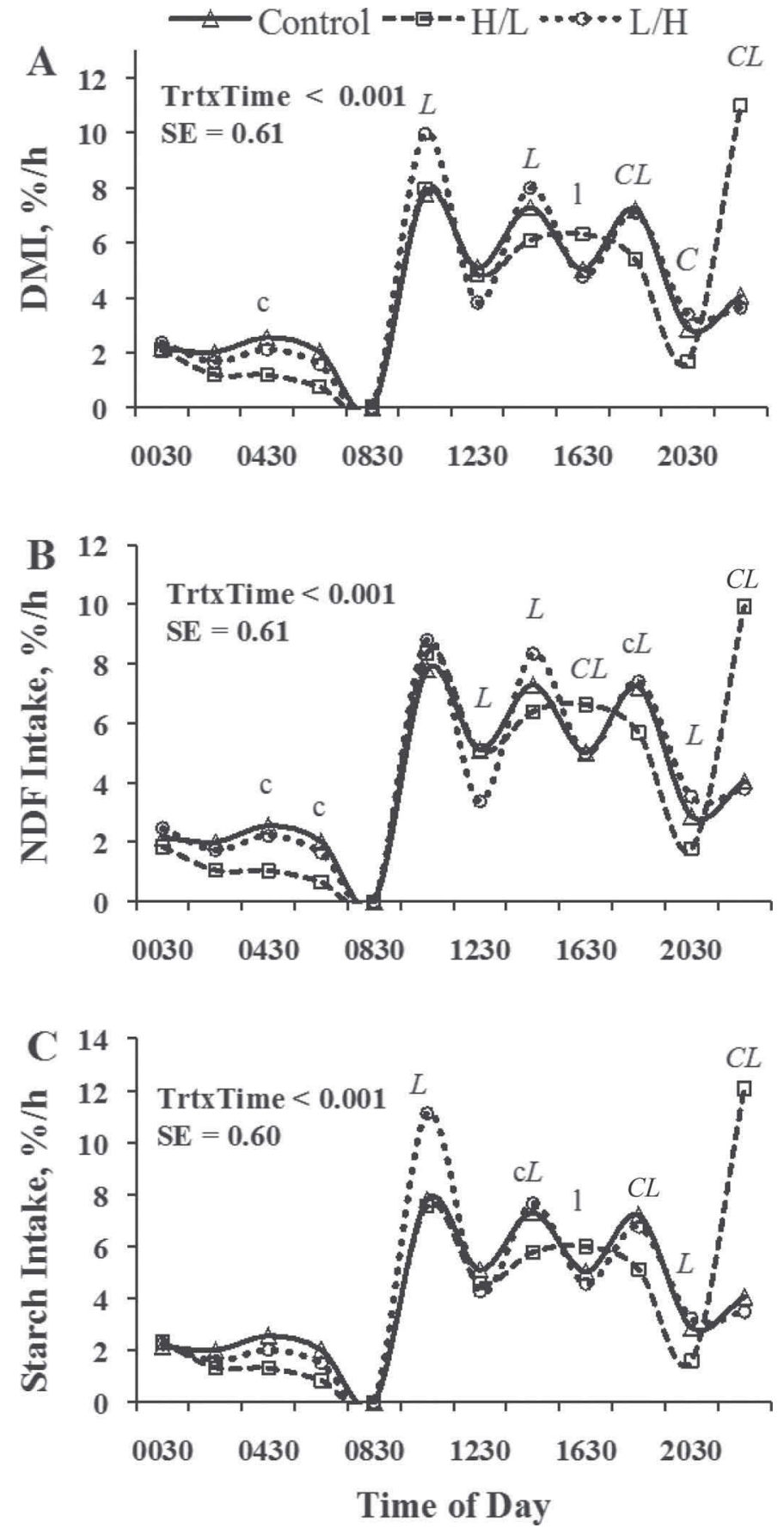

Figure 2. The effect of feeding 2 rations that differ in fiber and starch concentration at different times of the day on (A) DM, (B) $\mathrm{NDF}$, and $(\mathrm{C})$ starch intake across the day plotted as a percentage of daily intake of the nutrient each hour. Control diet was fed as a TMR once per day at $0900 \mathrm{~h} ; \mathrm{H} / \mathrm{L}$ was fed as high-fiber ration at $70 \%$ of daily offering at $0900 \mathrm{~h}$ and low-fiber ration at $30 \%$ of daily offering at $2200 \mathrm{~h}$; and $\mathrm{L} / \mathrm{H}$ was fed as low-fiber ration at $30 \%$ of daily offering at $0900 \mathrm{~h}$ and high-fiber diet at $70 \%$ of daily offering at $1300 \mathrm{~h}$. Preplanned contrasts at each time point are shown [control vs. H/L $(C=P<0.05$ and $\mathrm{c}=P<0.1) ; \mathrm{H} / \mathrm{L}$ vs. $\mathrm{L} / \mathrm{H}(L=P<0.05$ and $\mathrm{l}=$ $P<0.1)]$. Treatment by time interactions (Trt $\times$ Time) and SE are shown in each panel. Dark phase was approximately 0000 to $0500 \mathrm{~h}$. 
Table 3. The effect of feeding a single TMR or feeding 2 rations that differ in their fiber and starch concentration at different times of the day on feeding behavior over the entire day

\begin{tabular}{|c|c|c|c|c|c|c|c|}
\hline \multirow[b]{2}{*}{ Item } & \multicolumn{3}{|c|}{ Treatment $^{1}$} & \multirow[b]{2}{*}{ SEM } & \multicolumn{3}{|c|}{$P$-value ${ }^{2}$} \\
\hline & $\mathrm{CON}$ & $\mathrm{H} / \mathrm{L}$ & $\mathrm{L} / \mathrm{H}$ & & Trt & $\begin{array}{c}\mathrm{H} / \mathrm{L} \text { vs. } \\
\text { CON }\end{array}$ & $\begin{array}{c}\mathrm{H} / \mathrm{L} \text { vs. } \\
\mathrm{L} / \mathrm{H}\end{array}$ \\
\hline \multicolumn{8}{|l|}{ Meal } \\
\hline Size, kg & 2.8 & 2.7 & 2.9 & 0.20 & 0.24 & 0.44 & 0.10 \\
\hline Bouts/d & 9.9 & 9.8 & 10.2 & 0.48 & 0.68 & 0.82 & 0.40 \\
\hline Length, min & 34.1 & 33.3 & 31.3 & 1.42 & 0.28 & 0.63 & 0.28 \\
\hline Time, $\min / \mathrm{d}$ & 252 & 220 & 229 & 5.51 & $<0.001$ & $<0.001$ & 0.18 \\
\hline Rate, $\mathrm{kg} / \mathrm{min}$ & 0.104 & 0.093 & 0.105 & 0.009 & 0.13 & 0.09 & 0.07 \\
\hline \multicolumn{8}{|l|}{ Ratio $^{3}$} \\
\hline Hunger & 0.048 & 0.036 & 0.042 & 0.005 & 0.01 & $<0.01$ & 0.14 \\
\hline Satiety & 0.055 & 0.058 & 0.063 & 0.010 & 0.52 & 0.65 & 0.48 \\
\hline
\end{tabular}

${ }^{1}$ Least squares means. The control $(\mathrm{CON})$ cows were fed a TMR once per day at $0900 \mathrm{~h} ; \mathrm{H} / \mathrm{L}$ were fed a high-fiber ration at $70 \%$ of daily offering at $0900 \mathrm{~h}$ and a low-fiber ration at $30 \%$ of daily offering at $2200 \mathrm{~h}$; and $\mathrm{L} / \mathrm{H}$ were fed a low-fiber ration at $30 \%$ of daily offering at $0900 \mathrm{~h}$ and a high-fiber diet at $70 \%$ of daily offering at $1300 \mathrm{~h}$.

${ }^{2}$ Main effect of treatment (Trt) and preplanned contrasts (H/L vs. CON and H/L vs. L/H).

${ }^{3}$ Hunger ratio $=$ meal size divided by the preceding inter-meal interval; satiety ratio = meal size divided by the post-meal interval .

in $\mathrm{L} / \mathrm{H}$ compared with $\mathrm{H} / \mathrm{L}$, but the number of meals was fewer by 0.8 and the meal interval was decreased by $48 \mathrm{~min}$. In contrast, there were 1.2 fewer meals for $\mathrm{HF}$ when it was fed in $\mathrm{L} / \mathrm{H}$ compared with $\mathrm{H} / \mathrm{L}$. The hunger ratio was 2 -fold higher for the LF diet when fed in $\mathrm{L} / \mathrm{H}$ compared with $\mathrm{H} / \mathrm{L}$, but the hunger ratio of $\mathrm{HF}$ tended to decrease when fed in $\mathrm{L} / \mathrm{H}$ compared with $\mathrm{H} / \mathrm{L}$. Feed intake was higher after the morning feeding in $\mathrm{L} / \mathrm{H}$ compared with $\mathrm{H} / \mathrm{L}$ and may indicate increased palatability of the LF diet or an ability to consume the lower forage diet at a higher rate (Figure 2 ). It is noteworthy that a similar amount of feed was consumed in the first $2 \mathrm{~h}$ after feeding the LF diet in the morning and evening in $\mathrm{L} / \mathrm{H}$ and $\mathrm{H} / \mathrm{L}$.

\section{Milk Production and Milk FA Profile}

Milk yield and composition did not differ between $\mathrm{H} / \mathrm{L}$ and $\mathrm{CON}$, but $\mathrm{H} / \mathrm{L}$ tended to decrease milk yield by $2.4 \mathrm{~kg} / \mathrm{d}$ and decreased FCM yield by $3.1 \mathrm{~kg} / \mathrm{d}$ and fat yield by $0.12 \mathrm{~kg} / \mathrm{d}$ compared with $\mathrm{L} / \mathrm{H}$ treatment (Table 5). We found no effect of treatment on milk fat and protein concentrations or on MUN. We detected an overall effect of milking (a.m. vs. p.m.) on milk yield and composition but no treatment by milking interactions (Supplemental Table S1; http://dx.doi. org/10.3168/jds.2014-8859). Milk, fat, and protein yields were higher at the morning milking, whereas fat concentration was higher during the evening milking. This may be explained by the longer interval from the evening to the morning milking because the overnight milking interval was $14 \mathrm{~h}$; however, higher milk yield and lower milk fat percentage are normally reported for a.m. milkings (Quist et al., 2008; Rottman et al., 2014).

The concentrations of de novo and preformed FA in milk are indicators of the level of milk fat depression because de novo synthesized FA are decreased to a greater extent during diet-induced milk fat depression. Additionally, milk trans-10 C18:1 and trans-11 C18:1 are indicators of the capacity and predominant pathways of rumen biohydrogenation. Treatment had no effect on de novo synthesized FA, but H/L increased concentrations of preformed FA by nearly $5 \%$ compared with control $(P=0.02$; Table 5$)$. We found no effects of treatment on the concentrations and yields of trans-10 C18:1, trans-11 C18:1, and cis-9,trans-11 CLA or their precursor linoleic acid (C18:2n-6). Treatments had no other notable effects on the concentration of other milk FA (data not shown). Additionally, daily yield and yield by milking of individual FA predominantly followed the pattern of change in overall fat yield as few differences in milk FA profile were observed (data not shown, Supplemental Table S2; http://dx.doi.org/10.3168/ jds.2014-8859).

Lower milk and milk fat yields were not expected with $\mathrm{H} / \mathrm{L}$. However, the change in feeding behavior resulted in an active intake period after feeding the highstarch diet in the evening. Differences in milk fat yield did not appear to be due to classical diet-induced milk fat depression, because the trans FA intermediates were not changed. Additionally, the increase in preformed FA did not indicate the possibility of a propionate or insulin mechanism. Interestingly, the difference in milk and milk fat yields occurred primarily at the morn- 
Table 4. The effect of feeding 2 rations that differ in their fiber and starch concentrations at different times of the day on feeding behavior while consuming either the low-fiber or high-fiber diet

\begin{tabular}{|c|c|c|c|c|c|c|c|c|}
\hline \multirow[b]{2}{*}{ Item } & \multirow[b]{2}{*}{ Ration } & \multicolumn{2}{|c|}{ Treatment $^{1}$} & \multirow[b]{2}{*}{ SEM } & \multicolumn{4}{|c|}{$P$-value ${ }^{2}$} \\
\hline & & $\mathrm{H} / \mathrm{L}$ & $\mathrm{L} / \mathrm{H}$ & & Trt & Diet & $\begin{array}{c}\text { Trt } \times \\
\text { diet }\end{array}$ & $\begin{array}{c}\mathrm{H} / \mathrm{L} \text { vs. } \\
\mathrm{L} / \mathrm{H}\end{array}$ \\
\hline \multicolumn{9}{|l|}{ Meal } \\
\hline \multirow[t]{2}{*}{ Size, kg/d } & $\mathrm{L}$ & 2.7 & 3.4 & 0.24 & 0.25 & 0.04 & 0.03 & 0.02 \\
\hline & $\mathrm{H}$ & 2.7 & 2.5 & & & & & 0.42 \\
\hline Bouts/d & $\mathrm{L}$ & 3.1 & 2.3 & 0.36 & 0.48 & $<0.001$ & $<0.01$ & 0.06 \\
\hline Length, min & $\mathrm{H}$ & 35.1 & 31.2 & & & & & 0.93 \\
\hline \multirow[t]{2}{*}{ Interval, min } & $\mathrm{L}$ & 129 & 81 & 7.9 & 0.04 & 0.21 & $<0.001$ & $<0.001$ \\
\hline & $\mathrm{H}$ & 87 & 105 & & & & & 0.08 \\
\hline \multicolumn{9}{|l|}{ Eating } \\
\hline \multirow[t]{2}{*}{ Time, $\min / \mathrm{d}$} & $\mathrm{L}$ & 84 & 42 & 3.3 & 0.13 & $<0.001$ & $<0.001$ & $<0.001$ \\
\hline & $\mathrm{H}$ & 136 & 186 & & & & & $<0.001$ \\
\hline Rate, kg/min & $\mathrm{L}$ & 0.078 & 0.115 & 0.007 & 0.02 & 0.31 & $<0.001$ & 0.07 \\
\hline Satiety & $\mathrm{H}$ & 0.063 & 0.047 & & & & & 0.02 \\
\hline
\end{tabular}

${ }^{1}$ Least squares means. The $\mathrm{H} / \mathrm{L}$ cows were fed the high-fiber ration $(\mathrm{H})$ at $70 \%$ of daily offering at $0900 \mathrm{~h}$ and the low-fiber ration $(\mathrm{L})$ at $30 \%$ of daily offering at $2200 \mathrm{~h}$; and $\mathrm{L} / \mathrm{H}$ cows were fed $\mathrm{L}$ at $30 \%$ of daily offering at $0900 \mathrm{~h}$ and $\mathrm{H}$ at $70 \%$ of daily offering at $1300 \mathrm{~h}$.

${ }^{2}$ Significance of the effect of treatment (Trt), diet, and the interaction of treatment and diet (Trt $\times$ diet) and preplanned contrasts $(\mathrm{H} / \mathrm{L}$ vs. $\mathrm{CON}$ and $\mathrm{H} / \mathrm{L}$ vs. $\mathrm{L} / \mathrm{H})$.

${ }^{3}$ Hunger ratio $=$ meal size divided by the post-meal interval; satiety ratio $=$ meal size divided by the preceding inter-meal interval.

Table 5. The effect of feeding a single TMR or 2 rations that differ in their fiber and starch concentrations at different times of the day on daily milk yield and composition

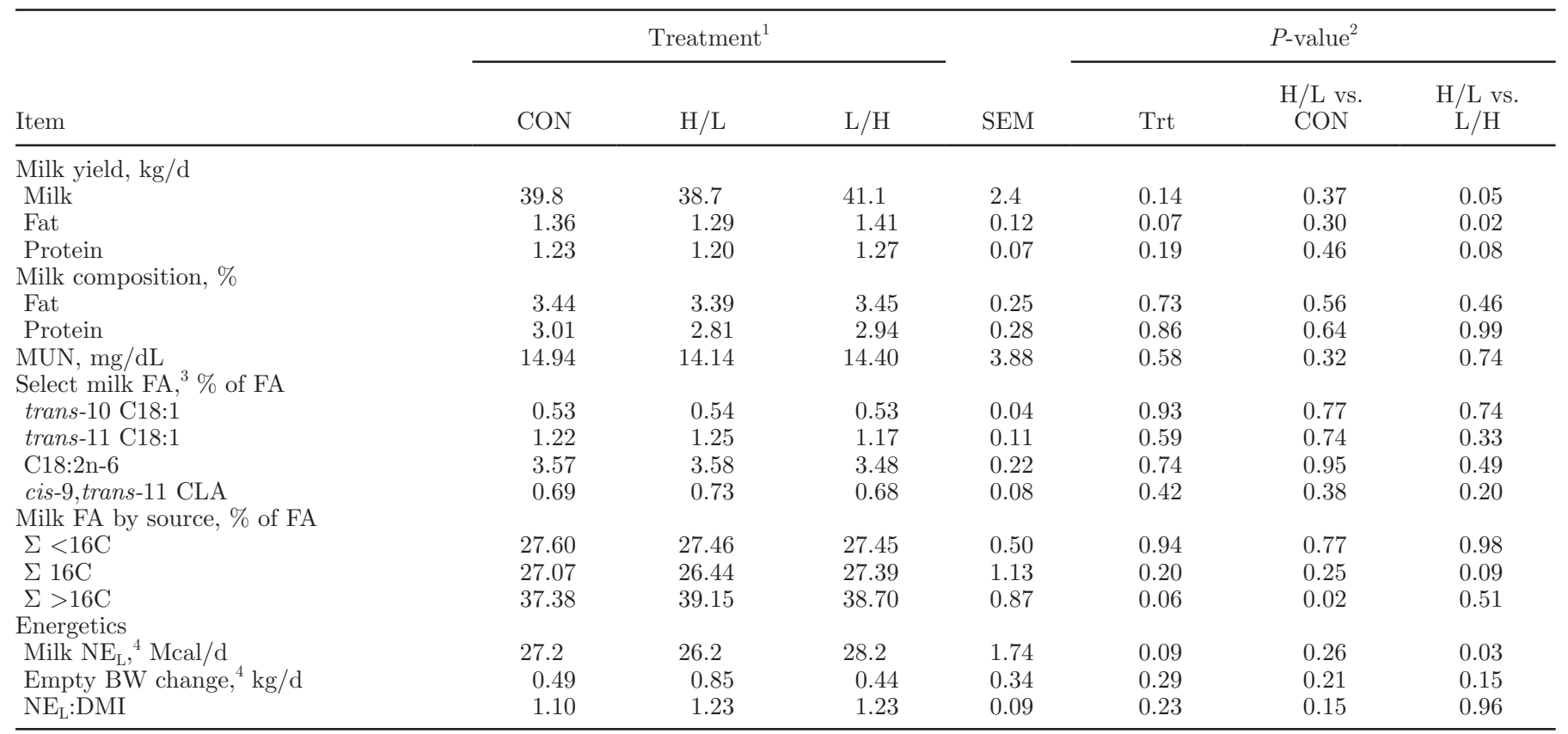

${ }^{1}$ Least squares means. The control (CON) cows were fed a TMR once per day at $0900 \mathrm{~h} ; \mathrm{H} / \mathrm{L}$ were fed a high-fiber ration at $70 \%$ of daily offering at $0900 \mathrm{~h}$ and a low-fiber ration at $30 \%$ of daily offering at $2200 \mathrm{~h}$; and $\mathrm{L} / \mathrm{H}$ were fed a low-fiber ration at $30 \%$ of daily offering at $0900 \mathrm{~h}$ and a high-fiber diet at $70 \%$ of daily offering at $1300 \mathrm{~h}$.

${ }^{2}$ Main effect of treatment (Trt) and preplanned contrasts (H/L vs. CON and H/L vs. L/H).

${ }^{3}$ trans-10, cis-12 CLA was below the level of detection.

${ }^{4}$ Calculated by NRC (2001) using Equation 2-16. 
ing milking (Supplemental Table S1; http://dx.doi. org/10.3168/jds.2014-8859). Acetate infusion increases milk fat yield (Sheperd and Combs, 1998), and feeding the high-starch diet during the night might have decreased the availability of acetate for milk fat synthesis during the overnight period. We expected to observe an increase in trans-10 $\mathrm{C} 18: 1$ with the $\mathrm{L} / \mathrm{H}$ treatment, but this did not occur. Rumen starch concentration and pool size are lowest before feeding, and Fickett and Allen (2002) reported decreased capacity for starch digestion before feeding. The dilution of starch in the rumen and decreased starch fermentation capacity may have reduced the effect of the $\mathrm{LF}$ diet fed in the morning in the $\mathrm{L} / \mathrm{H}$ treatment.

\section{Total-Tract Digestion}

Treatment had no effect on total-tract digestibility of DM, OM, NDF, or starch (Table 6). No change in digestibility and decreased intake in $\mathrm{H} / \mathrm{L}$ compared with CON resulted in a decrease in the amounts of DM, OM, and starch digested per day. Rumen pool sizes and digesta composition were modified by treatment and these results are reported in the companion paper (Ying et al., 2015). Changes in rumen pool sizes and digesta composition and no change in the extent of digestion indicate adaptability of rumen digestion to changes in nutrient intake across the day.

\section{BW Gain and Energetics}

Body weight observations are difficult in ruminants because of variation in rumen fill. Measuring BW after emptying the rumen decreases this variation and normally provides adequate power to observe BW changes, even within 21-d periods (e.g., Harvatine and Allen, 2006b). We detected no effect of treatment on EBW gain in the current experiment (Table 5). Efficiency was calculated as milk plus BW NE $/$ DMI because diets did not differ in nutrient composition, total-tract digestibility, or predicted energy density. By these metrics, feed efficiency did not differ between treatments. Although treatments had effects on intake and milk yield, these changes were energetically balanced.

\section{Plasma Metabolites and Hormones}

Plasma glucose, NEFA, insulin, and BUN are known to follow daily patterns and are metabolically important to the cow. With ANOVA, we detected a treatment by time interaction for plasma BUN, but not for plasma glucose, NEFA, or insulin, although differences between treatments were observed by the preplanned contrast at some time points (Figure 3; Supplemental Table S3; http://dx.doi.org/10.3168/jds.2014-8859). We detected a main effect of time on all 4 variables, as expected. Insulin, glucose, NEFA, and BUN fit a cosine function with a 24-h period in all treatments, and phase (time at peak) and amplitude (peak - mean) differed between $\mathrm{H} / \mathrm{L}$ and $\mathrm{CON}$ and $\mathrm{L} / \mathrm{H}$ for all variables (Table 7 ).

We observed a clear daily pattern for plasma insulin, with the lowest concentrations in the morning and the highest concentrations approximately $9 \mathrm{~h}$ later, coinciding with evening milking (Figure 3). There was no main effect of treatment, but $\mathrm{H} / \mathrm{L}$ tended to be higher than control at $2100 \mathrm{~h}$ and was higher at $0300 \mathrm{~h}$, which followed the high-intake period after delivery of the LF diet in the evening. The H/L treatment phase delayed the cosine function over $45 \mathrm{~min}$ and decreased the amplitude by $>20 \%$ compared with control and L/H. The

Table 6. The effect of feeding a single TMR or 2 rations that differ in their fiber and starch concentrations at different times of the day on apparent total-tract digestibility

\begin{tabular}{|c|c|c|c|c|c|c|c|}
\hline \multirow[b]{2}{*}{ Item } & \multicolumn{3}{|c|}{ Treatment $^{1}$} & \multirow[b]{2}{*}{ SEM } & \multicolumn{3}{|c|}{$P$-value ${ }^{2}$} \\
\hline & $\mathrm{CON}$ & $\mathrm{H} / \mathrm{L}$ & $\mathrm{L} / \mathrm{H}$ & & Trt & $\begin{array}{c}\mathrm{H} / \mathrm{L} \text { vs. } \\
\mathrm{CON}\end{array}$ & $\begin{array}{c}\mathrm{H} / \mathrm{L} \text { vs. } \\
\mathrm{L} / \mathrm{H}\end{array}$ \\
\hline DM & 16.2 & 15.4 & 15.8 & 0.59 & 0.13 & $<0.05$ & 0.28 \\
\hline $\mathrm{OM}$ & 15.4 & 14.6 & 15.0 & 0.58 & 0.11 & 0.04 & 0.22 \\
\hline NDF & 2.8 & 2.8 & 2.9 & 0.22 & 0.75 & 0.80 & 0.46 \\
\hline $\mathrm{DM}$ & 62.0 & 62.7 & 62.8 & 0.93 & 0.48 & 0.33 & 0.91 \\
\hline $\mathrm{OM}$ & 62.6 & 63.4 & 63.6 & 0.78 & 0.43 & 0.32 & 0.82 \\
\hline NDF & 32.7 & 33.9 & 34.8 & 1.71 & 0.66 & 0.60 & 0.71 \\
\hline Starch & 97.6 & 97.4 & 97.0 & 0.38 & 0.07 & 0.48 & 0.11 \\
\hline
\end{tabular}

${ }^{1}$ Least squares means. The control (CON) cows were fed a TMR once per day at $0900 \mathrm{~h} ; \mathrm{H} / \mathrm{L}$ were fed a high-fiber ration at $70 \%$ of daily offering at $0900 \mathrm{~h}$ and a low-fiber ration at $30 \%$ of daily offering at $2200 \mathrm{~h}$; and $\mathrm{L} / \mathrm{H}$ were fed a low-fiber ration at $30 \%$ of daily offering at $0900 \mathrm{~h}$ and a high-fiber diet at $70 \%$ of daily offering at $1300 \mathrm{~h}$.

${ }^{2}$ Main effect of treatment (Trt) and preplanned contrasts (H/L vs. CON and H/L vs. L/H). 
Table 7. Phase and amplitude of a cosine function with a 24-h period fit to plasma variables of cows fed a single TMR or 2 rations that differ in their fiber and starch concentrations at different times of the day

\begin{tabular}{|c|c|c|c|c|c|c|c|c|}
\hline \multirow[b]{2}{*}{ Item } & \multicolumn{3}{|c|}{$\begin{array}{c}\text { Phase }^{1} \\
\text { (time of day at peak, hh:mm) }\end{array}$} & \multicolumn{4}{|c|}{$\begin{array}{c}\text { Amplitude }^{2} \\
\text { (peak-mean) }\end{array}$} & \multirow[b]{2}{*}{$P$-value ${ }^{3}$} \\
\hline & $\mathrm{CON}$ & $\mathrm{H} / \mathrm{L}$ & $\mathrm{L} / \mathrm{H}$ & Unit & $\mathrm{CON}$ & $\mathrm{H} / \mathrm{L}$ & $\mathrm{L} / \mathrm{H}$ & \\
\hline Glucose & $\begin{array}{l}10.02 \\
04: 56\end{array}$ & $05: 46^{\mathrm{C}, \mathrm{L}}$ & $\begin{array}{l}10.09 \\
06: 34\end{array}$ & $\mathrm{mg} / \mathrm{dL}$ & $\begin{array}{l}0.00 \\
2.55\end{array}$ & $2.98^{\mathrm{C}}$ & 2.78 & $<0.01$ \\
\hline NEFA & $01: 54$ & $12: 31^{\mathrm{C}, \mathrm{L}}$ & $09: 22$ & $\mu \mathrm{Eq} / \mathrm{L}$ & 3.92 & $0.52^{\mathrm{C}, \mathrm{L}}$ & 7.23 & $<0.01$ \\
\hline BUN & $12: 49$ & $13: 34^{\mathrm{C}, \mathrm{L}}$ & $12: 43$ & $\mathrm{mg} / \mathrm{L}$ & 1.50 & $1.77^{\mathrm{C}, \mathrm{L}}$ & 1.42 & $<0.01$ \\
\hline
\end{tabular}

${ }^{1}$ Phase (time of day at peak) of a best-fit cosine function with a 24 -h period. The control (CON) cows were fed a TMR once per day at $0900 \mathrm{~h}$; $\mathrm{H} / \mathrm{L}$ were fed a high-fiber ration at $70 \%$ of daily offering at $0900 \mathrm{~h}$ and a low-fiber ration at $30 \%$ of daily offering at $2200 \mathrm{~h}$; and $\mathrm{L} / \mathrm{H}$ were fed a low-fiber ration at $30 \%$ of daily offering at $0900 \mathrm{~h}$ and a high-fiber diet at $70 \%$ of daily offering at $1300 \mathrm{~h}$.

${ }^{2}$ Amplitude (peak - mean) of a cosine function with a 24 -h period.

${ }^{3} P$-value of the zero amplitude test indicating significance of the cosine function. Preplanned contrasts were used to test for differences in phase and amplitude and significant differences are indicated by superscripts $\left({ }^{\mathrm{C}}=\mathrm{H} / \mathrm{L}\right.$ differed from $\mathrm{CON}$ and ${ }^{\mathrm{L}}=\mathrm{H} / \mathrm{L}$ differed from $\left.\mathrm{L} / \mathrm{H}\right)$.

$\rightarrow$ Control $--B-\cdot H / L \quad \cdots 0 \cdots \mathrm{L} / \mathrm{H}$

A

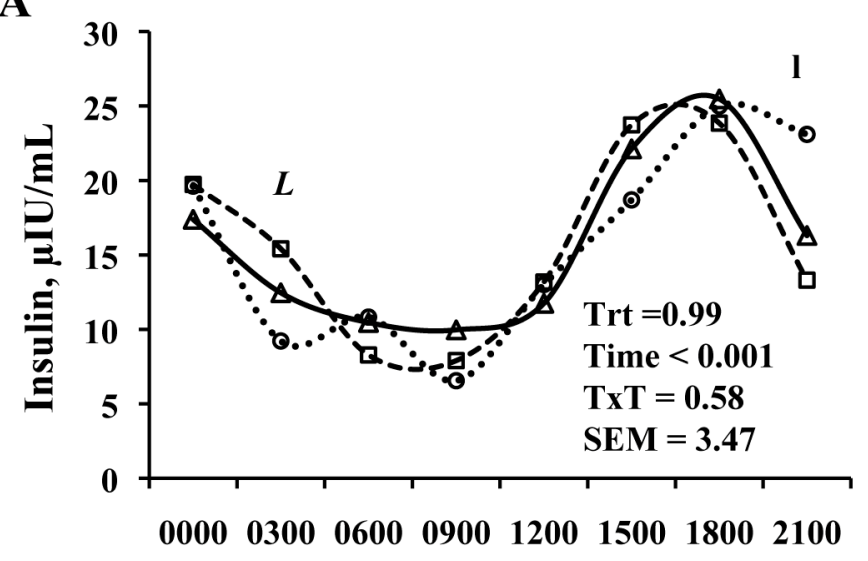

C

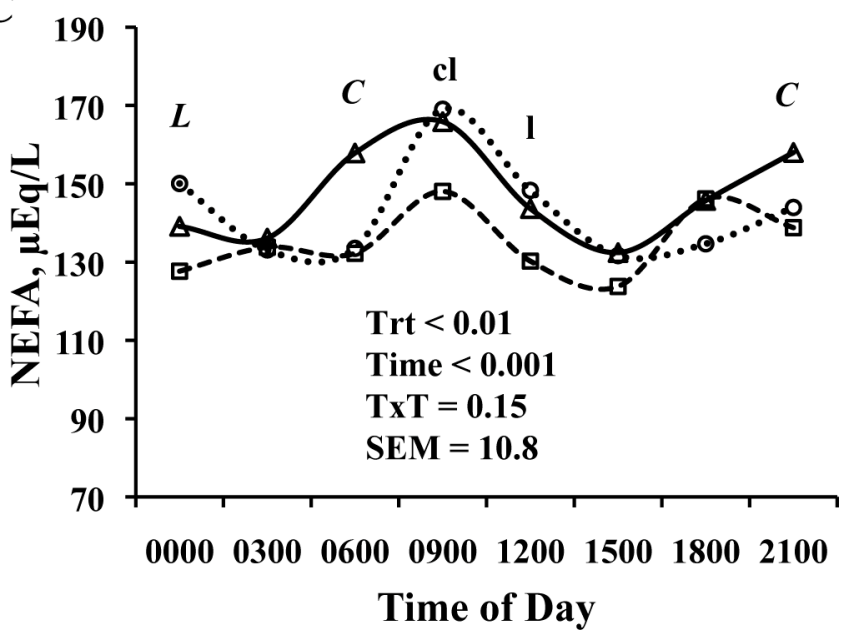



00000300060009001200150018002100

D

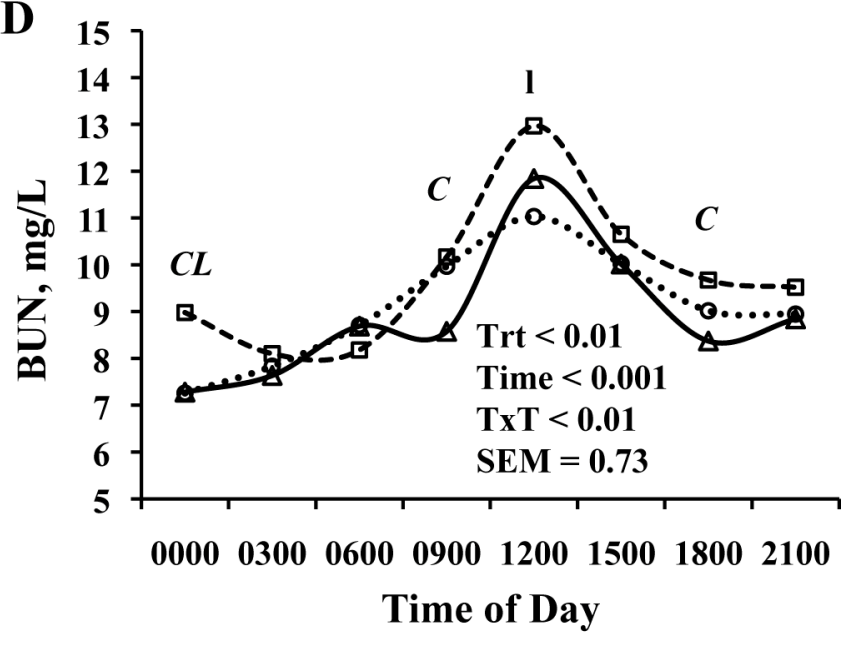

Figure 3. The effect of feeding 2 rations that differ in fiber and starch concentrations at different times of the day on (A) plasma insulin, (B) glucose, (C) NEFA, and (D) BUN. Control diet was fed as a TMR once per day at $0900 \mathrm{~h}$; H/L was fed as high-fiber ration at $70 \%$ of daily offering at $0900 \mathrm{~h}$ and low-fiber ration at $30 \%$ of daily offering at $2200 \mathrm{~h}$; and $\mathrm{L} / \mathrm{H}$ was fed as low-fiber ration at $30 \%$ of daily offering at 0900 $\mathrm{h}$ and high-fiber diet at $70 \%$ of daily offering at $1300 \mathrm{~h}$. Main effects of treatment (Trt) and time and their interaction $(\mathrm{T} \times \mathrm{T})$ are shown. Preplanned contrasts at each time point are shown [control vs. $\mathrm{H} / \mathrm{L}(C=P<0.05$ and $\mathrm{c}=P<0.1) ; \mathrm{H} / \mathrm{L}$ vs. $\mathrm{L} / \mathrm{H}(L=P<0.05$ and $\mathrm{l}=P$ $<0.1)$. Effect of treatment (Trt), time, and their interaction and SE are shown in each panel. Dark phase was approximately 0000 to $0500 \mathrm{~h}$. 
daily pattern of plasma glucose was the inverse of that of insulin, with the highest concentration in all treatments in the morning and a gradual decrease over the day to a nadir near evening milking (Figure 3). The cosine rhythm for the $\mathrm{H} / \mathrm{L}$ treatment was phase delayed 50 min compared with $\mathrm{CON}$ and phase advanced 48 min compared with $\mathrm{L} / \mathrm{H}$.

We detected a main effect of treatment $(P<0.01)$ for plasma NEFA (Figure 2). The $\mathrm{H} / \mathrm{L}$ treatment decreased daily average NEFA by 12 and $9 \mu \mathrm{Eq} / \mathrm{L}$ and decreased the amplitude of the daily rhythm by 3.4 and $6.7 \mu \mathrm{Eq} / \mathrm{L}$ compared with $\mathrm{CON}$ and $\mathrm{L} / \mathrm{H}$, respectively (Figure 2; Table 7). Plasma NEFA originate from mobilization of fat stores, and lower levels of NEFA may indicate that $\mathrm{H} / \mathrm{L}$ cows were in a more positive energy balance. Plasma NEFA peaked at $0900 \mathrm{~h}$ and a nadir occurred around $1500 \mathrm{~h}$ for all 3 treatments; however, a second peak was observed during the evening that differed between treatments. Plasma NEFA in the $\mathrm{H} / \mathrm{L}$ treatment was lower than that of $\mathrm{CON}$ or $\mathrm{L} / \mathrm{H}$ at 4 time points and tended to be lower at 2 others. Generally, the daily pattern of NEFA corresponded to the timing of nutrient intake. The peak at $0900 \mathrm{~h}$ occurred before morning feeding and followed the low-intake period overnight. The increase in NEFA from 1500 to $1800 \mathrm{~h}$ occurred before the evening feeding of the LF diet.

We detected a treatment by time interaction for plasma BUN $(P=0.05$; Figure 3$)$, and $\mathrm{H} / \mathrm{L}$ changed the phase and amplitude of the cosine function within a 24-h period compared with CON and L/H (Table 7). Plasma BUN in all 3 treatments peaked around noon, but plasma $\mathrm{BUN}$ in $\mathrm{H} / \mathrm{L}$ was phase delayed by over 45 min compared with that in $\mathrm{CON}$ and $\mathrm{L} / \mathrm{H}$. Plasma BUN gradually decreased and reached a nadir between 0000 and $0300 \mathrm{~h}$, with $\mathrm{H} / \mathrm{L}$ having higher concentrations than CON at $1800 \mathrm{~h}(P<0.01)$ and $0000 \mathrm{~h}(P$ $<0.001)$. The $\mathrm{H} / \mathrm{L}$ treatment also resulted in higher concentrations than in $\mathrm{L} / \mathrm{H}$ at $0000 \mathrm{~h}(P<0.001)$. The amplitude of the cosine function was increased by $\mathrm{H} / \mathrm{L}$ compared with $\mathrm{CON}$ and $\mathrm{L} / \mathrm{H}$, by 0.27 and $0.35 \mathrm{mg} / \mathrm{L}$, respectively.

\section{CONCLUSIONS}

Feeding a single TMR over the day fails to account for the daily pattern of feed intake. Feeding multiple rations that differ in fiber and starch concentration within a day provides an opportunity to match diet composition with the daily pattern of intake, but one must consider the effect of the additional feeding times on feeding behavior. Feeding a high-fiber ration during the morning and afternoon may reduce intake through physical fill, and feeding a low-fiber ration in the evening results in a very active feeding period after feed delivery that increases insulin and reduces NEFA. Contrary to our hypothesis, feeding a low-fiber ration in the morning followed by a high-fiber ration may be advantageous because it increased FCM yield. Although feeding a low-fiber ration first in the morning resulted in a high intake of starch, the low starch concentration of the rumen may reduce the effect of the high-starch entry compared with feeding the low-fiber ration in the evening after the active feeding period of the day. Modification of other dietary factors across the day may improve rumen function and milk synthesis and provides a fertile area for future research.

\section{ACKNOWLEDGMENTS}

Gratitude is expressed to M. Niu, A. R. Clarke, D. E. Rico, Grace Takacs, Ryan Fairbairn, Kaitlyn Proschold, and Megan Deeds (Penn State University, University Park, PA) for technical assistance and to all personnel at the Pennsylvania State University Dairy Cattle Research and Education Center for feeding and continuous care of animals. Research was supported by USDA Special Grant 2009-34281-20116 (to principal investigator Kevin Harvatine) and Penn State University.

\section{REFERENCES}

Albright, J. L. 1993. Feeding behavior of dairy cattle. J. Dairy Sci. $76: 485-498$.

AOAC International. 2000. Official Methods of Analysis. 17th ed. AOAC International, Gaithersburg, MD.

Coppock, C. E., D. L. Bath, and B. J. Harris. 1981. From feeding to feeding systems. J. Dairy Sci. 64:1230-1249.

Dado, R. G., and M. S. Allen. 1993. Continuous computer acquisition of feed and water intakes, chewing, reticular motility, and ruminal $\mathrm{pH}$ of cattle. J. Dairy Sci. 76:1589-1600.

DeVries, T. J., M. A. von Keyserlingk, and K. A. Beauchemin. 2003. Short communication: Diurnal feeding pattern of lactating dairy cows. J. Dairy Sci. 86:4079-4082.

DeVries, T. J., M. A. G. von Keyserlingk, and K. A. Beauchemin. 2005. Frequency of feed delivery affects the behavior of lactating dairy cows. J. Dairy Sci. 88:3553-3562.

Everett, R. W., and L. H. Wadell. 1970. Sources of variation affecting the difference between morning and evening daily milk production. J. Dairy Sci. 53:1424-1428.

Fickett, F. M., and M. S. Allen. 2002. Ruminal fluid effects on in vitro digestion kinetics of corn starch. J. Dairy Sci. 85(Suppl. 1):181. (Abstr.)

Firkins, J. L., M. Allen, B. Oldick, and N. St-Pierre. 1998. Modeling ruminal digestibility of carbohydrates and microbial protein flow to the duodenum. J. Dairy Sci. 81:3350-3369.

Girard, J. 1990. Metabolic adaptations to change of nutrition at birth. Biol. Neonate 58(Suppl. 1):3-15.

Harvatine, K. J., and M. S. Allen. 2006a. Effects of fatty acid supplements on feed intake, and feeding and chewing behavior of lactating dairy cows. J. Dairy Sci. 89:1104-1112.

Harvatine, K. J., and M. S. Allen. 2006b. Effects of fatty acid supplements on milk yield and energy balance of lactating dairy cows. J. Dairy Sci. 89:1081-1091.

Lammers, B. P., D. R. Buckmaster, and A. J. Heinrichs. 1996. A simple method for the analysis of particle sizes of forage and total mixed rations. J. Dairy Sci. 79:922-928. 
Mertens, D. R. 1987. Predicting intake and digestibility using mathematical models of ruminal function. J. Anim. Sci. 64:1548-1558.

Nikkhah, A., C. J. Furedi, A. D. Kennedy, G. H. Crow, and J. C. Plaizier. 2008. Effects of feed delivery time on feed intake, milk production, and blood metabolites of dairy cows. J. Dairy Sci. 91:4249-4260.

Niu, M., Y. Ying, P. A. Bartell, and K. J. Harvatine. 2014. The effects of feeding time on milk production, total-tract digestibility, and daily rhythms of feeding behavior and plasma metabolites and hormones in dairy cows. J. Dairy Sci. 97:7764-7776.

NRC. 2001. Nutrient Requirements of Dairy Cattle. 7th rev. ed. Natl. Acad. Sci., Washington, DC.

Quist, M. A., S. J. LeBlanc, K. J. Hand, D. Lazenby, F. Miglior, and D. F. Kelton. 2008. Milking-to-milking variability for milk yield, fat and protein percentage, and somatic cell count. J. Dairy Sci. 91:3412-3423

Rico, D. E., and K. J. Harvatine. 2013. Induction of and recovery from milk fat depression occurs progressively in dairy cows switched between diets that differ in fiber and oil concentration. J. Dairy Sci. 96:6621-6630

Rico, D. E., Y. Ying, and K. J. Harvatine. 2014. Effect of a highpalmitic acid fat supplement on milk production and apparent total-tract digestibility in high- and low-milk yield dairy cows. J. Dairy Sci. 97:3739-3751.

Rottman, L. W., Y. Ying, K. Zhou, P. A. Bartell, and K. H. Harvatine. 2014. The daily rhythm of milk synthesis is dependent on the tim- ing of feed intake in dairy cows. Physiol. Rep. 2:e12049. http:// dx.doi.org/10.14814/phy2.12049.

San Emeterio, F., R. B. Reis, W. E. Campos, and L. D. Satter. 2000. Effect of coarse or fine grinding on utilization of dry or ensiled corn by lactating dairy cows. J. Dairy Sci. 83:2839-2848.

Sheperd, A. C., and D. K. Combs. 1998. Long-term effects of acetate and propionate on voluntary feed intake by midlactation cows. J. Dairy Sci. 81:2240-2250.

Tolkamp, B. J., D. J. Allcroft, J. P. Barrio, T. A. Bley, J. A. Howie, T. B. Jacobsen, C. A. Morgan, D. P. Schweitzer, S. Wilkinson, M. P. Yeates, and I. Kyriazakis. 2011. The temporal structure of feeding behavior. Am. J. Physiol. Regul. Integr. Comp. Physiol. 301:R378-R393.

von Keyserlingk, M. A. G., and D. M. Weary. 2010. Feeding behaviour of dairy cattle: Measures and applications. Can. J. Anim. Sci 90:303-309.

Wildman, E. E., G. M. Jones, P. E. Wagner, R. L. Boman, H. F. Troutt, and T. N. Lesch. 1982. A dairy cow body condition scoring system and its relationship to selected production characteristics. J. Dairy Sci. 65:495-501.

Ying, Y., L. W. Rottman, C. Crawford, P. A. Bartell, and K. J. Harvatine. 2015. The effects of feeding rations that differ in neutral detergent fiber and starch concentration within a day on rumen digesta nutrient concentration, $\mathrm{pH}$, and fermentation products in dairy cows. J. Dairy Sci. 98:4685-4697. 10.3168/jds.2014-8873. 